\section{JIBM}

Journal of International Business and Management (JIBM) Journal Homepage: https://rpajournals.com/jibm

\title{
Antecedents of Product Innovation for Vietnamese SMEs: The Roles of Transformational Leadership and Organizational Culture
}

\author{
Ha Thanh Tung: \\ Tran Manh Dung \\ Le Ba Phong* \\ Hanoi University of Industry, Bactuliem, Hanoi, Vietnam ${ }^{13}$ \\ National Economics University, Hanoi, Vietnam ${ }^{2}$
}

\begin{abstract}
Innovation capability is regarded the fundamental factor for firms to survive and achieve competitive advantage in the context of increasing competitive pressure. The purpose of this paper is to elaborate the impacts of transformational leadership (TL) on innovation product via mediating role of a certain form of organizational culture namely collaborative culture. The paper used Structural Equations Modeling (SEM) to examine the relationship among these latent factors using survey data gathered from 215 participants of 61 medium and small-sized firms in Vietnam. The findings of this study highlight the significant impact of TL on product innovation compared to the impact of collaborative culture on product innovation. This study reveals that collaborative culture significantly serves as a crucial mediator in linking the effects of TL on product innovation. Importantly, the findings of this study have advanced the understanding and brought new initiatives on key antecedents by which CEOs and managers should follow and focus their efforts to improve product innovation capability for Vietnamese SMEs. Keywords: Transformational leadership; Organizational culture; Collaborative culture; Product innovation; Innovation capability
\end{abstract}

*Corresponding author: Le Ba Phong; Email: lebaphong.vn@gmail.com DOI: https://doi.org/10.37227/JIBM-2022-01-5292

\section{Introduction}

In response to the rapidly changing and unpredictable factors of business environment, scholars highlight the important role of increasing innovation capability for firms as it is recognized as an optimal solution to create core value and competitive advantage (Le \& Lei, 2019; Than et al., 2019; Cao et al., 2021). Innovation capability is fast becoming a crucial factor in firm performance and survival as a result of the evolution of the competitive environment (Le, 2021; Shehzad et al., 2021) because it can be a source of competitive advantage (Le \& Lei, 2018). Innovation helps firms adapt well with the uncertainty of the external environment and become one of the most important factors leading to the success of the business in the long term, particularly in the dynamic markets (Phong \& Tung, 2021).

Scholars considered innovation as the capabilities of creating new ideas or behaviors relating to a system, policy, program, device, process, product or service (Hage, 1999; Nguyen et al., 2021). Previous studies emphasized innovation capability as an essential for the survival and growth of organizations but many firms do not how to develop it properly (Le, 2020; Le et al., 2020; Gui et al., 2021). Thus, many academic works have been implemented to explore the effective pathways leading 
to enhancing innovation capability. Researchers have discovered many factors having positive impacts on innovation capability, such as: organizational culture (Martins \& Terblanche, 2003; Yang et al., 2018); human resource management (Cao et al., 2021; Than et al., 2021); personal mastery (García-Morales et al., 2007); knowledge management (Nguyen et al., 2021; Gui et al., 2021); total quality management (Hung et al., 2011); organizational learing (Liao et al., 2008; García-Morales et al., 2012) and leadership styles (Khan, et al., 2019; Lei et al., 2019; Lei et al., 2021). However, literature on relationship between transformational leadership (TL), organizational culture and innovation capability is still sparse and limited. As a result, this study will clarify the relationship among these factors by exploring the mediating role of collaborative culture between TL and product innovation in the context of Vietnamese SMEs. The research issue is very urgent and necessary by following reasons:

First, innovation capability of an organization is widely considered as a means of enhancing organizational performance however, many firms do not expand it properly, especially in the context of SMEs (Yang et al., 2018; Purwati et al., 2021). In particular, Cao et al. (2021) stressed the needs of exploring the key antecedents for fostering innovation capability of SMEs.

Second, previous studies indicated the important role of organizational resources and called for the research on the relationship between organizational resources and innovation capability (Anderson et al., 2014; Lei et al., 2017; Phong \& Tung, 2021). Although organizational culture is viewed as a key organizational resource to create long-term success and competitive advantage for firms (Büschgens et al., 2013; Yang et al., 2018). The empirical study on collaborative cultureinnovation relationship is still scare and limited (Yang et al., 2018; Le et al., 2020). Therefore, exploring of how collaborative culture affects innovation capability in term of product innovation is very significant and important.

Finally, there have been many studies showing the positive influence of TL on organizational performance and capability for change and innovation (Hui et al., 2018; Sengphet et al., 2019; Le \& Lei, 2019; Le \& Tran, 2020; Ha \& Le, 2021; Le, 2021; Nguyen et al., 2021), according to author knowledge, the understanding of how TL affects product innovation via specific mediating mechanisms such as collaborative culture is still limited and largely speculative.

Based on above arguments, to fill the theoretical gaps, this study is implemented to answer the following research question:

- Does TL positively impact product innovation?

- Does collaborative culture positively predict product innovation?

- Does collaborative culture mediate the relationship between TL and product innovation? This study used structural equations modeling (SEM) to test the correlation between the constructs based on the data of 215 participants of 61 medium and small-sized firms in Vietnam. This study is expected to provide theoretical and practical initiatives on the effective pathway for improving product innovation SMEs.

\section{The Effects of TL on Product Innovation}

\section{Theoretical Background}

Transformational leaders characterized leaders who stress in communicating about organizational goals in a clear way; proceeding as the leading force; taking part in proactive coaching; encouraging new skill development between employees and unceasingly looking for new opportunities to create the development for their firm (Chen et al., 2013; Le \& Lei; 2017; Islam et al., 2018 Van et al., 2018). Transformational leadership is perceived as one of the most effective leadership styles affected key outcomes of an organization such as: knowledge capital, human capital (Birasnav et al., 2011), organizational performance (Son et al., 2020), organizational justice (Phong \& Son, 2020); and innovation performance (Jia et al., 2018). Hence, investigating the TL-innovation capability relationship has become very common in the current literature.

Innovation capability is one of the most important dynamics that enable firms to attain competitive advantage and success in long term in comparison with the key rivals (Nguyen et al., 2018; Le \& Lei, 2019; Lei et al., 2021). Scholars defined innovation as the capabilities of creating 
new products, services, work processes, and management procedures to gain an organizational competitive advantage (Drucker, 2014; Le \& Lei, 2019). Innovation capability is classified into many types such as product and process innovation (Tsai et al., 2001), exploitative and exploratory innovation (Than et al., 2021); innovation speed and quality (Le \& Le, 2018), radical and incremental innovation (Nguyen et al., 2021), and frugal innovation capability (Le, 2021). This study focus on TL-innovation capability relationship in term of product innovation because innovation product is widely regarded as the main form of innovation capability (Le \& Lei, 2019; Wahyono, 2019). Wherein, product innovation refers to organization's capability of providing differentiated or new products/services in the market to acquire customers' satisfaction (Le \& Lei, 2019; Rasheed et al., 2021).

Leadership widely accepted as a determinant factor for innovation. Previous works highlighted that transformational leaders directly affect innovation by creating appropriate conditions within an organization to positively assist the process of generating and implementing activities of innovation (Ha et al., 2019; Le \& Lei, 2019. Scholars indicated that TL builds up an innovative culture by encouraging innovation initiatives from employees (Tajasom et al., 2015; Phong et al., 2018). Van et al. (2018) pointed out that, transformational leaders directly or indirectly influence firm's innovation performance through improving learning capability of a firm. Le and Lei (2019) confirmed that TL significantly impacts firm's product innovation by creating an atmosphere conducive to knowledge sharing activities among employees in organizations. Many recent studies also show evidence supporting positive effects of TL on innovation capability in terms of product and process innovation (Le \& Lei, 2019; Wahyono, 2019; Rasheed et al., 2021), so this study proposed that (Figure 1):

H1. TL positively affects product innovation capability

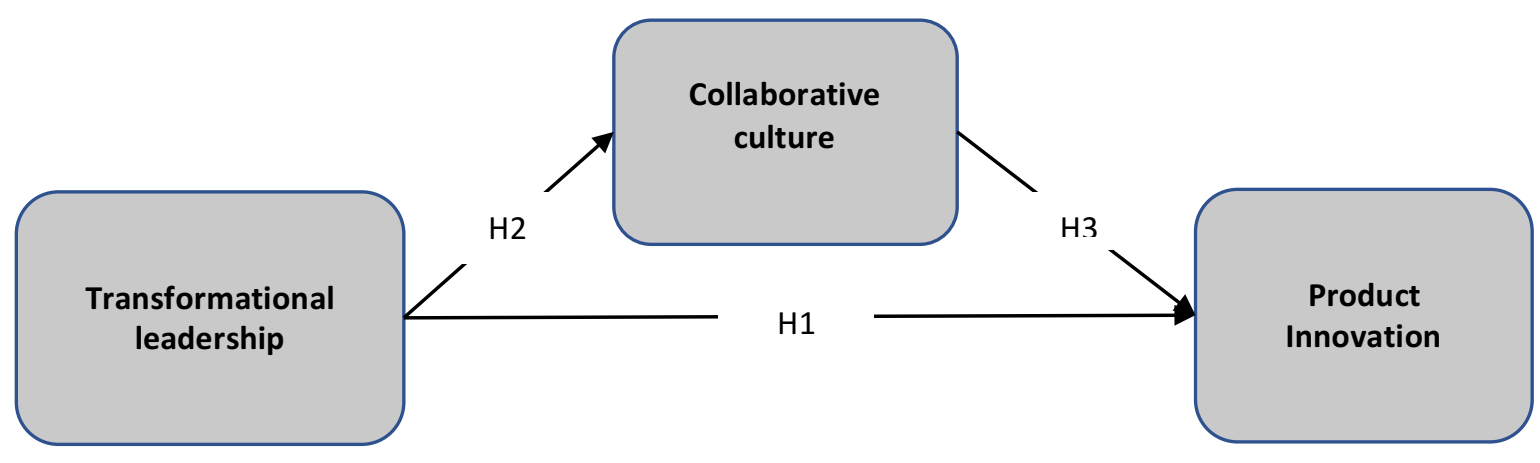

Figure 1. The proposal research model

\section{Collaborative Culture Mediates the Effect of TL on Product Innovation}

Schein (2004) identified and defined organizational culture as the employees' shared values, beliefs or perceptions of the organization and its environment. According to Cameron and Quinn (2011, 2016), organizational culture has four main types namely Adhocracy culture, Clan culture (collaborative culture), Hierarchy culture, and Market culture. This study pays great attention to the role of collaborative culture due to its important role for organizational innovation (Yang et al., 2018; Le et al., 2020). Le et al. (2020) regarded collaborative culture as the core values of organizational culture that characterized by long-term vision and advance management of the change, team-work, communication, risk assumption, respect and empowerment, and promoting the knowledge of individuals. Basically, this type of culture is built and developed based on the mutual respect, care and support each other (Lei et al., 2017; Le et al., 2020).

Regarding the relationship between leadership/TL and organizational/collaborative culture, Jung (2001) found that leadership plays decisive roles in creating, changing, and institutionalizing organizational culture. Sarros et al. (2011) asserted that leadership is widely believed to have close correlation with organizational culture as evidence that senior leaders have a strategic position to 
shape and develop organizational culture. Especially, prior studies showed that the basic attributes of transformational leaders are very important to establish and maintain a cooperative atmosphere in their organization (Demir, 2008; Mitchell, 2012; Nguyen et al., 2021). In addition, several studies have also showed that TL practice is requited to build the trust among employees (Le \& Lei, 2017; Le \& Lei, 2018), which in turn serves as key determinant of collaborative climate in organizations (Cao \& Zhang, 2011; Kucharska et al., 2016; Kucharska, 2017). Based on above analysis, this study suggests that TL is one of main forces to shape the nature of collaborative culture. So we propose that:

\section{H2. TL positively predicts collaborative culture in organizations}

Current literature showed positive evidence on the important role and the significant effect of collaborative culture values on innovation capability. For example, Tushman and O'Reilly (1997) indicated that collaborative-focused values (such as shared values, behaviour and beliefs about the organization) lie at the heart of organization innovation. Martin and Terblanche (2003) pointed out that typical values and behaviours of collaborative culture (e.g., mistake handing, idea generating, continuous learning culture, risk taking, competitiveness, support for change, conflict handing, and open communication) facilitate the innovation activities in an organization. DeCusatis (2008) affirmed that collaboration itself has been found to be associated with innovative and creative outcomes. Barczak et al. (2010) realized that successful innovation capability depends on the effectiveness of collaboration and knowledge sharing in organizations. Kumar et al., (2016) noted that increasing of the degree of relationship and collaboration will promote the capability adjustment of existing processes and new product development. Recently, the empirical study of Yang et al. (2018) showed that collaborative culture's values are the condition and crucial for firms to foster product and process innovation. So, we hypothesize that:

\section{H3. Collaborative culture is positively related to product innovation capability}

Above discussion provides supports for the mediating role of collaborative culture by manifesting that TL positively predict collaborative culture which, in turn, servers as a driving force for fostering product innovation capability. So, following hypothesis is tested:

H4. Collaborative culture mediates the effects of TL on product innovation

\section{Sample and Measures}

\section{Research Methodology}

This study used a survey method to collect data from 61 small and medium firms in Vietnam during the period from September to November, 2020. Approached firms are diverse in industries, sizes and operating in distinct fields. We contacted with the representatives of the HR departments in person or via e-mail and interpret the research goals and request for their help in distributing questionnaires and collecting data. To meet the purpose of the research, the participants in our study need to be the heads of department, and key employees from major departments/divisions of administration, marketing, and research and development to make the certain that they have multiple and full knowledge on the key outcomes and strategic orientations of organizations. This study distributed 390 questionnaires and received back 296 ones in the formal data collection, of which 215 are valid (55.1\% validity rate). We used the Armstrong \& Overton's (1977) method to assess potential nonresponse bias. We implemented the chi-square and independent sample t-tests to estimate the first 75 participants and the last 75 ones through the demographic factors namely age and gender. The outcomes indicated that there is no significant differentiation among the two participant groups $(p>$ $0.05)$.

\section{Measurement}

To ensure the validity and reliability of the study, items used to measure variables were developed from prior studies. All constructs were measured using multiple items and all items were assessed using a five-point Likert-type scale, ranging from " $1=$ strongly disagree" to " $5=$ strongly agree". 
This study used four items designed by Podsakoff et al. (1996) for diverse aspects of TL. These items were used in the research of Le and Lei (2018) to reflect participants' perceptions of their leader about TL style. A sample items is "my supervisors are capable of motivating and guiding their colleagues on the job. To measure collaborative culture, we used eight items obtained from Le et al.'s (2020) research to measure of a culture whose members foresee changes, support dialogue and encourage respect, teamwork, risk and diversity. A sample item is "collaboration and co-operation among the different duties and departments are encouraged". Finally, this study used six items adopted from the research of Le and Lei (2019) and Liao et al. (2007) to measure product innovation, a sample item is "Our firm often develops new products and services well accepted by the market".

\section{Data Analysis Methods}

To avoid the influences of common method bias, the paper has implemented the Harman's singlefactor test to examine for common method bias. The findings pointed out that the overall variance is less than the 50\% threshold for substantive common method variance. Such result has shown that common method bias is not a concern. The paper also applied the SEM to check the proposal hypotheses in initial proposal model. Besides, this paper has also implemented a bootstrapping procedure for the significance tests. Statistical Package for the Social Sciences (SPSS 22) and Analysis of Moment Structures (AMOS 22) are employed for assessing the data gathered from the 215 respondents in 61 small and medium firms.

\section{Measurement Model}

\section{Results}

This study has performed a series of tests to assess the validity and reliability of the constructs before testing the proposal hypotheses (Table 1). Specifically, to assess the reliability of the latent variables, basing on suggestion of Nunnally and Bernstein (1994), this study used the Cronbach's alpha coefficients of each one that require greater than the level of 0.7. Confirmatory factor analysis (CFA) to test for the convergent validity; comparing the squared correlations between the latent variables and square root of average variance extracted (AVE) to test the discriminant validity of measures (Fornell \& Larcker, 1981).

Table 1. Descriptive statistics and average variances extracted from constructs

\begin{tabular}{lllllllll}
\hline Construct & AVE & CR & C $\alpha$ & Mean & SD & TL & CC & PP \\
\hline Transformational leadership (TL) & 0.73 & 0.95 & 0.95 & 3,51 & 0.66 & $\mathbf{0 . 8 5}$ & & \\
Collaborative culture (CC) & 0.81 & 0.94 & 0.94 & 3.54 & 0.61 & 0.71 & $\mathbf{0 . 9 0}$ & \\
Product innovation (PI) & 0.67 & 0.92 & 0.92 & 3.59 & 0.58 & 0.78 & 0.71 & $\mathbf{0 . 8 2}$ \\
\hline
\end{tabular}

Note: $C \alpha \geq 0.7 ; C R \geq 0.7 ; A V E \geq 0.5$; Diagonal elements (in bold) are the square root of the AVE.

Results in Table 1 showed AVE, CR, mean, standard deviation (SD) and C $\alpha$. These results have provided the evidence for the evidence on the reliability of scales as well as the convergent validity of constructs.

In addition, to evaluate the discriminant validity of latent constructs in the proposal model, the paper used the squared correlations among the latent factors to control whether they are smaller than each latent variable's square root of AVE or not. Table 1 also points out that the squared correlations among the latent factors are lower than square root of AVE of each one (diagonal elements in bold). Thus, according to Fornell and Larcker (1981), the results have provided significant support for the scales' discriminant validity. 
Fit indices of the measurement model obtained from CFA model show that the model fits the data (see Table 2).

Table 2. Overall fit index of the CFA model

\begin{tabular}{lll}
\hline Fit index & Scores & Recommended value \\
\hline Absolute fit measures & & \\
CMIN/df & 2.372 & $\leq 2 ; \leq 5^{\circ}$ \\
GFI & 0.854 & $\geq 0.90 ; \geq 0.80^{\circ}$ \\
RMSEA & 0.080 & $\leq 0.8 ; \leq 0.10^{\circ}$ \\
Incremental fit measures & & \\
NFI & 0.921 & $\geq 0.90 ;$ \\
AGFI & 0.811 & $\geq 0.90 ; \geq 0.80^{\circ}$ \\
CFI & 0.952 & $\geq 0.90 ;$ \\
Notes: a Acceptability: acceptable; $b$ Acceptability: marginal &
\end{tabular}

\section{Findings}

The paper applied Structural equation model with procedures of maximum likelihood estimation to examine the proposal hypotheses. The findings indicated that the fit indices of the proposal model are satisfactory $(\chi=313.10 ; \mathrm{df}=132 ; \mathrm{RMSEA}=0.08 ; \mathrm{GFI}=0.854 ; \mathrm{CFI}=0.952 ; \mathrm{TLI}=0.945)$. The results have pointed out that the correlation among latent factors fit the data. The main findings of this study are shown in Table 4 and Figure 2.

\section{Direct Effect Analysis}

The results in Table 3, and Figure 2 verified that direct effects of independent factors on dependent factors are found to be significant supported hypotheses $\mathrm{H} 1, \mathrm{H} 2$, and $\mathrm{H} 3$.

Specifically, influence of TL on product innovation is statistically significant, favoring for hypothesis $\mathrm{H} 1$. The results showed that the impacts of TL on product innovation $(\beta=0.55 ; p<$ $0.001)$ is very positive and significant.

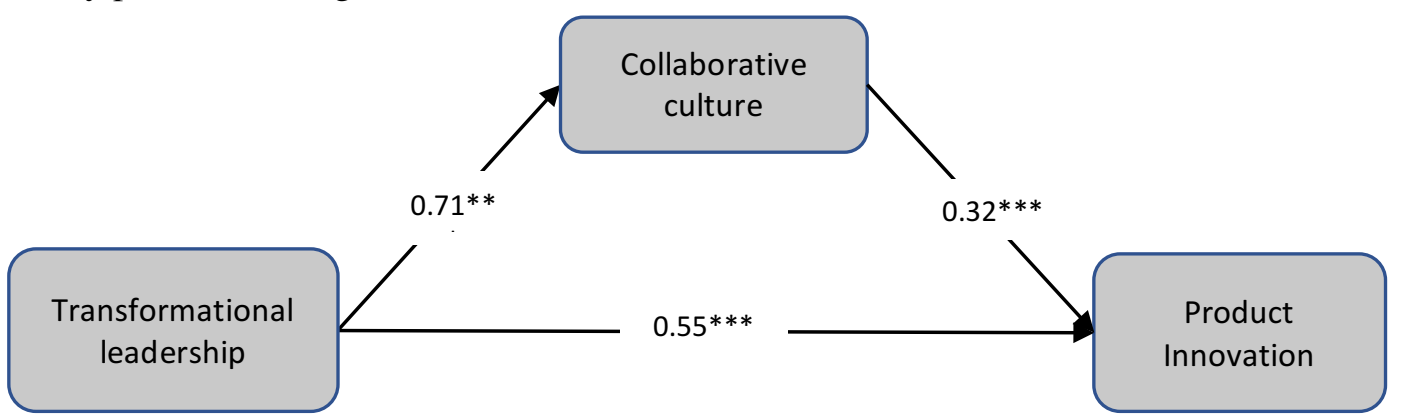

Fiaure 2. Path coefficients of the structural model

As shown in Table 3 , the influences of TL on collaborative culture are also statistically significant and quite large ( $\beta=0.71 ; p<0.001)$, so hypothesis $\mathrm{H} 2$ is supported.

The results in Table 3 also confirmed the positive effect of collaborative culture on product innovation $(\beta=0.323 ; p<0.001)$. Hypothesis of $\mathrm{H} 3$ is, therefore, also supported.

Table 3. Structural Model Results

\begin{tabular}{lccrl}
\hline Hypotheses & Effect & Estimate & \multicolumn{1}{c}{$\begin{array}{l}\text { value } \\
\text { vesults }\end{array}$} \\
\hline H1a. Transformational leadership $\rightarrow$ Product Innovation & + & $0.553^{* *}$ & 7.248 & Supported \\
H2. Transformational leadership $\rightarrow$ Collaborative culture & + & $0.715^{* * *}$ & 11.911 & Supported \\
H3. Collaborative culture $\rightarrow$ Product Innovation & + & $0.323^{* * *}$ & 4.500 & Supported \\
\hline
\end{tabular}

Notes: $* * * P<0.001 ; * * P<0.05$. 


\section{Indirect Effect and Total Effect}

The paper does not just give evidence about the direct influence of TL on product innovation capability. It also demonstrates how collaborative culture mediate the relationship between TL and product innovation.

According to the recommendation of Preacher and Hayes (2008), to show the evidence for the mediating role of collaborative culture between TL and product innovation, the paper has applied procedure of bootstrap confidence intervals with 3,000 iterations to examine and assert the indirect effects' immensity and statistical significance. The results are shown in the Table 4.

Table 4. Test for indirect effects

\begin{tabular}{|c|c|c|c|c|c|}
\hline \multirow[b]{2}{*}{ Path } & \multirow{2}{*}{$\begin{array}{l}\text { Direct } \\
\text { effects }\end{array}$} & \multirow{2}{*}{$\begin{array}{l}\text { Indirect } \\
\text { effects }\end{array}$} & \multirow{2}{*}{$\begin{array}{l}\text { Total } \\
\text { effects }\end{array}$} & \multicolumn{2}{|c|}{ Bias-corrected confidence intervals } \\
\hline & & & & $\begin{array}{c}\text { Lower } \\
\text { confidence level }\end{array}$ & $\begin{array}{c}\text { Upper } \\
\text { confidence level }\end{array}$ \\
\hline $\mathrm{TL} \rightarrow \mathrm{CC} \rightarrow \mathrm{PI}$ & $0.553 * *$ & $0.231 * * *$ & $0.784 * * *$ & 0.154 & 0.319 \\
\hline
\end{tabular}

Table 4 showed indirect effect of TL on product innovation $(\beta=0.231 ; p<0.001)$ is statistically significant and lies in the confidence interval (from 0.154 to 0.319 ). Consequently, hypothesis $\mathrm{H} 4$ is significantly supported. In other words, the result of testing in Table 4 has confirmed that collaborative culture significantly mediates the effects of TL on product innovation. This reveals that TL significant affect product innovation capability directly or indirectly via mediating role of collaborative culture.

\section{Discussions and Implications}

Innovation is evolving in the context of changing and rapid developments in the corporate climate and is becoming a critical solution for companies to boost market efficiency and gain sustainable competitive advantages (Le \& Lei, 2019; Tian et al., 2018). Organizationa capability for innovation enables firms to effectively meet customer demands, stay ahead of competitors, match the organization's capabilities with competitive advantages, and increase growth opportunities (Le, 2020; Rujirawanich et al., 2011). Consequently, most firms have adopted innovation as an appropriate approach to meet increasing business complexity and competition, especially in term of SMEs (Saunila, 2016; Cao et al., 2021). However, many firms are still facing challenges and do not know how to improve it correctly and effectively (Le \& Lei, 2018; Nguyen et al., 2019; Lei et al., 2019). This has attracted and created great awareness and motivation among scholars to explore for what allowing organization to successfully innovate (Yang et al., 2018; Van et al., 2018; Le \& Lei, 2019; Le, 2020). The examination of the hypotheses proposed in the current study have significantly increased the deeper understanding on the antecedents of product innovation. The paper has provided new and useful initiatives on both theory and practice in the fields of leadership, organizational culture, and innovation management by following main points.

First, the paper contributes to bridge the theoretical cavity on TL-innovation relationship by proposing an integrated model discussing the influences of TL on a specific type of organizational culture called collaborative culture, which in turn affects product innovation. The empirical findings have verified the correlation among the latent variables in the proposal model and confirmed the key role of TL in stimulating collaborative climate and product innovation of organizations. More importantly, the findings revealed that the influence of TL on product innovation is greater than the impact of collaborative culture on product innovation. The findings imply that to improve product innovation of small and medium firms, managers/directors should pay much attention to practice TL style. In line with previous study (e.g., Le \& Lei, 2019; Nguyen et al., 2021), this study suggests that to foster product innovation leaders and practitioners should pay attention to practice TL style by considering employees as the firm's valuable resource; building emotional links with its followers and inspiring them to higher values. 
Second, another important contribution of this study is providing a deeper insight on the relationship between TL and collaborative culture. The findings have supported the positive influence of TL on collaborative culture and revealed that TL is one of the most influential leadership styles. Accordingly, TL practices not only increase specific aspects of innovation capability (Le \& Lei, 2019; Le, 2020; Le, 2021) but also serve as an important antecedent of many key organizational outcomes such as collaborative culture. These findings are very interesting and valuable because collaborative climate is the main source of collective strength, helping organizations overcome all obstacles and achieve a competitive edge in its environment (Yang et al., 2018; Le et al., 2020).

Finally, this study contributes to advance the understanding on the right and effective pathway to successfully improve product innovation for Vietnamese SMEs. By assessing the effects of TL on product innovation via mediating role of collaborative culture, the findings of this study have supported the idea that TL practices will create significant impacts on product innovation directly or indirectly through positive effects of collaborative culture. This finding is very important because most Vietnamese SMEs often face a scarcity of financial resources to innovate (Le, 2021; Gui et al., 2021; Lei et al., 2021). In other words, the research results have helped Vietnamese SMEs identify a new path as well as a suitable and low-cost choice to improve product innovation.

\section{Research Limitation and Future Directions}

Beside significant contributions, the paper still has some certain limitations. First, the paper use cross-sectional design, thus it might expose the cases that causal correlations might alter in the longrun. Therefore, longitudinal studies are necessary to surpass this restriction and confirm the findings of this study. Second, the paper has not investigated the impacts of various moderating or/and mediating factors like industry type and firm size in the connection among the latent factors. Future works should inspect and examine deeper the correlation among them in case of having these mediators and moderators to bring more valuable understanding for scholars and practitioners. Third, the paper is only performed in the circumstances of medium and small firms, so the future work should examine the relationship among the latent factors in the broader circumstances to provide more meaning for firms Fourth, collaborative culture goes along with the core and important values of organizational culture can be the main drive of many key organizational outcomes. Accordingly, future research should focus on exploring potential benefits of collaborative culture in the relation to the other strategic variables such as knowledge management capability, competitive advantage and organizational performance to bring deeper insight on the role and benefit of collaborative culture. Finally, Leadership plays a decisive role in enhancing organizational creativity and innovation capability (Le \& Lei, 2019). Leaders are widely seen as the key drivers of promoting or inhibiting innovation management in the organizations (Gui et al., 2021; Nguyen et al., 2021). Bel (2010) indicated that different leadership styles are likely to have different impacts on employee involvement and commitment, which in turn influence the climate for innovation management. Accordingly, future research should investigate the influences of different leadership styles (such as ethical leadership, knowledge-oriented leadership, and servant leadership) on innovation product for better understanding on the significance of certain leadership leading to innovation.

\section{Conclusions}

Overall, by investigating the impacts of transformational leadership on product innovation via mediating role of a certain form of organizational culture namely collaborative culture, this study has significantly increased the knowledge and insight on the key antecedents leading to innovation. This study has highlighted the importance of practicing TL style (such as caring for exchanging information about organizational goals and visions in a clear and positive way; acting as the leading force in key activities of organization; proactively and positive coaching employees; building appropriate policy and mechanism to encourage new skill development among employees; and continuously looking and identifying new opportunities to bring the development for organization) to foster a collaborative climate and innovation capability for Vietnamese SMEs. 


\section{References}

Anderson, N., Potočnik, K., \& Zhou, J. (2014). Innovation and creativity in organizations: A stateof-the-science review, prospective commentary, and guiding framework. Journal of Management, 40(5), 1297-1333.

Armstrong, J. S., \& Overton, T. S. (1977). Estimating nonresponse bias in mail surveys. Journal of marketing research, 14, 396-402.

Barczak, G., Lassk, F., \& Mulki, J. (2010). Antecedents of team creativity: An examination of team emotional intelligence, team trust and collaborative culture. Creativity and Innovation Management, 19(4), 332-345.

Bel, R. (2010). Leadership and innovation: Learning from the best. Global Business and Organizational Excellence, 29(2), 47-60.

Birasnav, M., Rangnekar, S., \& Dalpati, A. (2011). Transformational leadership and human capital benefits: The role of knowledge management. Leadership \& Organization Development Journal, 32(2), 106-126.

Büschgens, T., Bausch, A., \& Balkin, D. B. (2013). Organizational culture and innovation: A metaanalytic review. Journal of Product Innovation Management, 30(4), 763-781.

Cameron, K., \& Quinn, R. E. (2016). Organizational culture assessment instrument. In.

Cameron, K. S., \& Quinn, R. E. (2011). Diagnosing and changing organizational culture: Based on the competing values framework: John Wiley \& Sons.

Cao, M., \& Zhang, Q. (2011). Supply chain collaboration: Impact on collaborative advantage and firm performance. Journal of operations management, 29(3), 163-180.

Cao, T. T., Le, P. B., \& Nguyen, N. T. M. (2021). Impacts of high-involvement HRM practices on organizational innovation capability: the mediating mechanism of tacit and explicit knowledge sharing. International Journal of Innovation Science.

Chen, Y., Jermias, J., \& Lee, G. (2013). The Performance Implication of Goal Achievability in Incentive Contracts and Feedback. Paper presented at the CAAA Annual Conference.

DeCusatis, C. (2008). Creating, growing and sustaining efficient innovation teams. Creativity and Innovation Management, 17(2), 155-164.

Demir, K. (2008). Transformational leadership and collective efficacy: The moderating roles of collaborative culture and teachers' self-efficacy. Eurasian Journal of Educational Research, $33,93-112$.

Drucker, P. (2014). Innovation and entrepreneurship: Routledge, New York.

Fornell, C., \& Larcker, D. F. (1981). Evaluating structural equation models with unobservable variables and measurement error. Journal of marketing research, 18(1), 39-50.

García-Morales, V. J., Jiménez-Barrionuevo, M. M., \& Gutiérrez-Gutiérrez, L. (2012). Transformational leadership influence on organizational performance through organizational learning and innovation. Journal of business research, 65(7), 1040-1050.

García-Morales, V. J., Lloréns-Montes, F. J., \& Verdú-Jover, A. J. (2007). Influence of personal mastery on organizational performance through organizational learning and innovation in large firms and SMEs. Technovation, 27(9), 547-568.

Garza Mitchell, R. L. (2012). Doing the right thing: Ethical leadership and decision making. New directions for community colleges, 2012(159), 63-72.

Gui, L., Lei, H., \& Le, P. B. (2021). Determinants of radical and incremental innovation: the influence of transformational leadership, knowledge sharing and knowledge-centered culture. European Journal of Innovation Management, In Press.

Ha, A. T. L., Phong, L. B., \& Hui, L. (2019). Leadership and Organizational Learning: The Determinants of Innovation Speed and Innovation Quality in Vietnamese Firms. Journal of Management and Strategy, 10(1), 29-37.

Ha, T. T., \& Le, P. B. (2021). What Are the Sources of Organizational Change Capability? The Role of Transformational Leadership and Organizational Justice. International Journal of Business Administration, 12(2). 
Hage, J. T. (1999). Organizational innovation and organizational change. Annual review of sociology, 25, 597-622.

Hui, L., Phouvong, S., \& Phong, L. B. (2018). Transformational Leadership Facilitates Innovation Capability: The Mediating Roles of Interpersonal Trust. International Journal of Business Administration, 9(3), 1-9

Hung, R. Y. Y., Lien, B. Y.-H., Yang, B., Wu, C.-M., \& Kuo, Y.-M. (2011). Impact of TQM and organizational learning on innovation performance in the high-tech industry. International Business Review, 20(2), 213-225.

Islam, M. A., Jantan, A. H., Rahman, M. A., Hamid, A. B. A., Mahmud, F. B., \& Hoque, A. (2018). Leadership Styles for Employee Empowerment: Malaysian Retail Industry. Journal of Management Research, 10(4), 27-40.

Jia, X., Chen, J., Mei, L., \& Wu, Q. (2018). How leadership matters in organizational innovation: a perspective of openness. Management Decision, 56(1), 6-25.

Jung, D. I. (2001). Transformational and transactional leadership and their effects on creativity in groups. Creativity Research Journal, 13(2), 185-195.

Khan, A. M., Jantan, A. H. B., Salleh, L. B. M., Dato'Mansor, Z., Islam, M. A., \& Hosen, S . (2019). The impact of transformational leadership effects on innovative work behavior by the moderating role of psychological empowerment. Journal of Reviews on Global Economics, $8,925-938$.

Kucharska, W. (2017). Relationships between trust and collaborative culture in the context of tacit knowledge sharing. Journal of Entrepreneurship, Management and Innovation, 13(4), 6178.

Kucharska, W., \& Kowalczyk, R. (2016). Trust, Collaborative Culture and Tacit Knowledge Sharing in Project Management-a Relationship Model. Humanistic Management Network, Research Paper Series, 49/16, 159-166.

Le Ba, P. (2021). Tăng cường khả năng đổi mới thanh đạm cho các doanh nghiệp Việt Nam: Vai trò của lãnh đạo chuyên đổi và khả năng quản trị tri thức của doanh nghiệp. Tạp chí Kinh tếvà Phát triển(286), 68-77.

Le, B. P., \& Tran, Q. T. (2020). Leadership Practice for Building Trust of Followers: Decisive Factors of Organizational Performance. SEISENSE Journal of Management, 3(2), 45-57.

Le, P. B. (2021). Determinants of frugal innovation for firms in emerging markets: the roles of leadership, knowledge sharing and collaborative culture. International Journal of Emerging Markets, Inpress, DOI: 10.1108/IJOEM-02-2021-0258, 1-20.

Le, P. B., \& Lei, H. (2017). How transformational leadership supports knowledge sharing: Evidence from Chinese manufacturing and service firms. Chinese Management Studies, 11(3), 479497.

Le, P. B., \& Lei, H. (2018a). The effects of innovation speed and quality on differentiation and lowcost competitive advantage: The case of Chinese firms. Chinese Management Studies, 12(2), 305-322.

Le, P. B., \& Lei, H. (2018b). The mediating role of trust in stimulating the relationship between transformational leadership and knowledge sharing processes. Journal of Knowledge Management, 22(3), 521-537.

Le, P. B., \& Lei, H. (2019). Determinants of innovation capability: the roles of transformational leadership, knowledge sharing and perceived organizational support. Journal of Knowledge Management, 23(3), 527-547.

Le, P. B., Lei, H., Le, T. T., Gong, J., \& Ha, A. T. (2020). Developing a collaborative culture for radical and incremental innovation: the mediating roles of tacit and explicit knowledge sharing. Chinese Management Studies, 14(4), 957-975.

Lei, H., Gui, L., \& Le, P. B. (2021). Linking transformational leadership and frugal innovation: the mediating role of tacit and explicit knowledge sharing. Journal of Knowledge Management, 25(7), 1832-1852. 
Lei, H., Khamkhoutlavong, M., \& Le, P. B. (2021). Fostering exploitative and exploratory innovation through HRM practices and knowledge management capability: the moderating effect of knowledge-centered culture. Journal of Knowledge Management (In press), 25(8), 19261946.

Lei, H., Le, P. B., \& Nguyen, H. T. H. (2017). How Collaborative Culture Supports for Competitive Advantage: The Mediating Role of Organizational Learning. International Journal of Business Administration, 8(2), 73-85.

Lei, H., Phouvong, S., \& Le, P. B. (2019). How to foster innovative culture and capable champions for chinese firms: an empirical research. Chinese Management Studies, 13(1), 51-69.

Liao, S.-H., Fei, W.-C., \& Chen, C.-C. (2007). Knowledge sharing, absorptive capacity, and innovation capability: an empirical study of Taiwan's knowledge-intensive industries. Journal of Information Science, 33(3), 340-359.

Liao, S.-h., Fei, W.-C., \& Liu, C.-T. (2008). Relationships between knowledge inertia, organizational learning and organization innovation. Technovation, 28(4), 183-195.

Martins, E., \& Terblanche, F. (2003). Building organisational culture that stimulates creativity and innovation. European Journal of Innovation Management, 6(1), 64-74.

Nguyen, T. N., Shen, C. H., \& Le, P. B. (2021). Influence of transformational leadership and knowledge management on radical and incremental innovation: the moderating role of collaborative culture. Kybernetes, https://doi.org/10.1108/K-12-2020-0905.

Nunnally, J. C., \& Bernstein, I. (1994). Elements of statistical description and estimation. Psychometric Theory 3 Edition, McGraw-Hill, New York.

Phong, L. B., Hui, L., \& Son, T. T. (2018). The mediating role of knowledge sharing in linking transformational leadership and innovation. The 5th IBSM International Conference on Business, Management and Accounting, Hanoi University of Industry, Vietnam., http://caal-inteduorg.com/proceedings/ibsm5/HRM2-12.pdf, 791-799.

Phong, B. L., \& Tung, H. T. (2021). Influences of Organizational Factors on Organizational Capability for Innovation: An empirical Study from Vietnamese Firms. Journal of International Business Management, 4(6), 01-14.

Phong, L. B., \& Son, T. T. (2020). The Link Between Transformational Leadership and Knowledge Sharing: Mediating Role of Distributive, Procedural and Interactional Justice. Journal of Information Knowledge Management, 19(3), 2050020.

Podsakoff, P. M., MacKenzie, S. B., \& Bommer, W. H. (1996). Transformational leader behaviors and substitutes for leadership as determinants of employee satisfaction, commitment, trust, and organizational citizenship behaviors. Journal of Management, 22(2), 259-298.

Preacher, K. J., \& Hayes, A. F. (2008). Asymptotic and resampling strategies for assessing and comparing indirect effects in multiple mediator models. Behavior research methods, 40(3), 879-891.

Purwati, A., Budiyanto, B., Suhermin, S., \& Hamzah, M. J. A. (2021). The effect of innovation capability on business performance: The role of social capital and entrepreneurial leadership on SMEs in Indonesia. 7(2), 323-330.

Sarros, J. C., Cooper, B. K., \& Santora, J. C. (2011). Leadership vision, organizational culture, and support for innovation in not-for-profit and for-profit organizations. Leadership \& Organization Development Journal, 32(3), 291-309.

Shehzad, M. U., Zhang, J., \& Le, P. B. (2021). Role of collaborative culture and knowledge management process for stimulating radical and incremental innovation: a comparative moderation approach. Business Process Management Journal, 27(7), 2021-2050.

Tajasom, A., Hung, D. K. M., Nikbin, D., \& Hyun, S. S. (2015). The role of transformational leadership in innovation performance of Malaysian SMEs. Asian Journal of Technology Innovation, 23(2), 172-188. 
Than, S. T., Nguyen, C. H., Tran, T. Q., \& Le, P. B. (2019). Building competitive advantage for vietnamese firms: The roles of knowledge sharing and innovation. International Journal of Business Administration, 10(4), 1-12.

Than, S. T., Le, P. B., \& Le, T. T. (2021). The impacts of high-commitment HRM practices on exploitative and exploratory innovation: the mediating role of knowledge sharing. VINE Journal of Information Knowledge Management Systems, https://doi.org/10.1108/VJIKMS10-2020-0196

Tian, M., Deng, P., Zhang, Y., \& Salmador, M. P. (2018). How does culture influence innovation? A systematic literature review. Management Decision, 56(5), 1088-1107.

Tushman, M. L., \& O'Reilly, C. A., III. (1997). Winning through innovation: A practical guide to leading organizational change and renewal In: Harvard Business School Press, Boston, MA.

Van, N. T., Phong, L. B., \& Loan, L. T. (2018). Antecedents of Innovation Capability: The Role of Transformational Leadership and Organizational Learning. International Journal of Business Administration, 9(5), 1-10.

Wahyono, W. (2019). The mediating effects of product innovation in relation between knowledge management and competitive advantage. Journal of Management Development, 39(1), 1830 .

Yang, Z., Nguyen, V. T., \& Le, P. B. (2018). Knowledge sharing serves as a mediator between collaborative culture and innovation capability: an empirical research. Journal of Business \& Industrial Marketing, 33(7), 958-969 